\title{
Exploring EFL Student-Teachers' Metacognitive Awareness in Extensive Listening
}

Vera Nursyarah, Nur Arifah Drajati, Ngadiso

Master Degree of English Education Department Universitas Sebelas Maret, Surakarta, Indonesia

Email: nursyarahvera@gmail.com

How to cite this paper: Nursyarah, V., Drajati, N. A., \& Ngadiso, N. (2019). Exploring EFL Student-Teachers' Metacognitive Awareness in Extensive Listening . International Journal of Language Teaching and Education, 3(2), 98-107. https://doi.org/10.22437/ijolte.v3i2.7961

Accepted: November 20, 2019

Published: December 31, 2019

Copyright (c) 2019 International Journal of Language Teaching and Education

This work is licensed under the Creative Commons Attribution International License (CC BY 4.0). http://creativecommons.org/licenses by $/ 4.0 /$

(c) (i)

\begin{abstract}
Listening plays a vital role in the field of foreign and second language learning. The study aimed to explore which types of metacognitive awareness and how participants employed it when they practiced Extensive listening outside the classroom. The participants involved in the study were two undergraduate students in one of the state universities in Indonesia. Both of them are males majoring in English Department in teaching training faculty. The study used a Case study research design. Semi-structured interview and documentation were used as a tool to collect the data. The instrument was adapted and derived based on the Metacognitive Awareness Listening theory Questionnaire (MALQ). The finding of the study revealed that when students practiced Extensive listening outside the classroom, they used problem-solving strategy, person Knowledge, and mental translation. The study implies that students should raise awareness in the listening process by knowing about themselves, listening Task and strategies they use to help their listening development. Besides that, teachers need to use metacognitive instruction to increase students' metacognitive listening awareness.
\end{abstract}

\section{Subject Areas}

Listening

Keywords

Case study; EFL students; Extensive listening; MALQ

\section{Introduction}

Listening is a fundamental language skill to develop in L2 learning (Dunkel, 1991; Rost, 2002; Richards, 2005; Vandergrift \& Goh, 2012). Listening is not only considered just a skill to comprehend but also to acquire linguistic knowledge (Richards, 2005; Rost, 2002). Still, listening comprehension is often regarded as a challenging skill that causes frustration for second and foreign language learners (Graham, 2011). Factors affecting listening difficulties in second language listening have been extensively discussed by a lot of scholarly works (Anderson \& Lynch, 1988; Dunkel, 1991; Goh, 1999, 2000; Huang, 2004, 2006; 
Miller, 2009; Renandya, \& Farrell, 2010; Rost, 1990, 1994, 2005). Most listening applied in the language classroom is only testing rather than teaching how to comprehend (Thorn, 2009; Brown, 2011). In other words, teachers rarely taught how to listen effectively even though they are aware that listening skill is prominent to second or foreign language learners (Mendelsohn, 2001; Berne, 2004; Vandergrift, 2007).

To deal with the problems arisen in listening comprehension, Goh (2010) suggested "metacognitive instruction" as a process-based approach to assist second or foreign language learners in the process of listening. Metacognition has a vital role in second language acquisition (Byrnes, 1996; Costa, 2001; Sternberg, 1998; Wenden, 1998). As Vandergrift (2006) said that students with Metacognitive abilities tend to understand their learning style and capacity, regulate and control their learning process in an active way, and finding more effective learning methods in their ways. Improvement of metacognition also assists learners to become more aware of their learning process and demands of learning tasks. Hence, they can know how to select appropriate learning strategies in different contexts. Accordingly, language learners must have metacognitive awareness (MAL) in the L2 listening process.

The conception of MAL was derived from the idea of 'metacognition' created by Flavell (1979). It refers to students' awareness of learning and thinking (Goh, 2008). Metacognitive awareness of listening was defined as students' metacognitive knowledge of their perceptions and their understanding about themselves, their listening demands, their cognitive goals, and their approach to the task and their listening strategies (Vandergrift, Goh, Mareschal \& Tafaghodtari).

Several scholars have investigated the study of metacognitive listening strategy's awareness on learning. For Instance, Goh (2000) found that higher achiever listeners showed a higher degree of awareness of their listening difficulties. Vandergrift (2007) also reported that there is a causal relationship between metacognitive instructions which statistically shows significant development in listening performance. Several studies in the EFL context have also examined the relationship between metacognitive listening strategies awareness and language proficiency (Shirani Bidabadi and Yamat, 2011). Other studies also revealed that language learners applied metacognitive strategies to deal with listening difficulties (Bacon, 1992; Goh, 1998; Mareschal, 2002; Vandergrift, 2003).

In some studies, Metacognitive awareness plays a crucial role in learning outside the classroom, particularly in extensive listening activities. They are also more aware of how to regulate themselves. Liyanage, Bartlett, Birch, \& Tao (2012) found that EFL students tend to use metacognitive outside the classroom rather than inside the classroom. Nisbet, Tindall, and Arroyo (2005) studied the relationship between self-reliance with the improvement of learning strategies and autonomy. Oxford (2001) argued that the development of language learning strategies leads to self-reliance (i.e. autonomy). He suggested that language learning outside the classroom supports students to be more autonomous. In other words, by practicing extensive listening outside the classroom, students have opportunities to be more self regulated and learn autonomously. 
However, there is only a dearth of studies concerning metacognitive listening awareness in Extensive Listening which are done outside the classroom. Therefore, the goal of the current study is to understand what types of English student-teachers metacognitive awareness and how they are aware of their listening process in an extensive listening activity outside the classroom.

\section{Literature review}

The term 'metacognition' was coined by an American psychologist, Flavell, in the 1970s. He defined Metacognition as "Knowledge concerning one's cognitive processes and products or anything related to them" (Flavell, 1976, p. 232). Flavell (1976) then divided metacognitive knowledge into three types: person, task, and strategy knowledge. Person knowledge is someone's knowledge about himself as a learner regarding his learning. Task knowledge is one's knowledge about the nature, demand, and purpose of a learning task. Strategy knowledge is one's knowledge about the strategies that they use in a learning activity to achieve learning goals. Later, it was applied to language learning by Wenden (1987). Metacognition is also defined as “thinking about one's thinking" (Vandergrift, et al., 2006, p. 432). Wenden (1991) has also applied Flavell's typology and categorized Metacognitive knowledge into three types including Person knowledge, task knowledge, and strategic knowledge. Person knowledge is learners' knowledge about themselves as learners which includes human factors that facilitate or hinder learning (Wenden 1998). Task knowledge is learners' knowledge of the purpose and demands of a task. Strategic knowledge including learners' knowledge about learning strategies and their understanding about when and how they apply those strategies (Wenden 1998).

Meanwhile, Metacognitive awareness of listening was defined as students' cognitive appraisal or students' metacognitive knowledge of their perceptions about themselves, their understanding of listening demands, their cognitive goals, and their approach to the task and their strategies (Vandergrift et al., 2006). Vandergrift et al (2006) categorized metacognitive awareness into five types, i.e., problem-solving, planning and evaluation, mental translation, person knowledge, and directed attention. Problem-solving refers to strategies that students use to guess the meaning of the oral text they have listened to and to monitor their understanding in the listening process. Planning and evaluation strategies are strategies that students use to prepare themselves for listening and to evaluate the results of their listening efforts (Vandergrift \& Tafaghodtari, 2010).

Furthermore, mental translations are listening strategies that students use to avoid mental translation if they are to become skilled listeners (Vandergrift, 2003). Person knowledge strategies include listeners' perceptions regarding the difficulty presented by L2 listening and their self-efficacy in L2 listening (Sparks and Ganschow, 2001). Directed attention refers to strategies that students use to keep their concentration and to stay focus on listening such as pause and replay when they start to lose their concentration or focusing harder when facing difficulty when they try to understand (Rost, 2002).

Recently, several studies have examined metacognitive awareness of listening in second language learning. Altuwairesh (2016) reported that participants, rather than other strategies, have mostly used 
problem-solving strategies and direct attention. Furthermore, Barne (2004) examined some research studies which focus on more and less proficient listeners. It is found that the high achiever listeners are more able to guess the meaning of words based on what they hear in their past experiences; which implies that they use problem-solving strategy.

\section{Methodology}

\subsection{Research Design}

The study was an exploratory case study that investigated students' metacognitive awareness in extensive listening activities. The study was conducted at one of the state universities in Indonesia. The participants were two male English student-teachers studying in the third semester. The data obtained from two instruments namely interviews and documentation.

\subsection{Participants}

The participants involved in the study were English student-teachers who enrolled in a Bachelor's Degree in the English Department in one of the state universities in Indonesia which were selected based on a purposeful sampling strategy (Patton, 2002). They are two males who met the criteria of the study. The criteria of participants are EFL students in the English Department who are used to listening to English outside the classroom from various resources such as BBC, TED, English movies or songs, short English movies, etc. The participants were English student-teachers who were used to listening to English from various resources outside the classroom. Their ages ranged between 18-22 years old.

\subsection{Data collection}

The instruments used in the study were semi-structured interviews and documentation. The instruments adapted from Vandergrift et al. (2006)'s concept of Metacognitive awareness of listening which derived from Flavell's (1979) metacognition theory and the concept of extensive listening by Renandya and Farrrel (2011) derived from Extensive Reading theory coined by Day and Bamford (2002). In-depth interviews were conducted several times to delve deeper into participants' opinions, belief and feelings about their metacognitive awareness in extensive listening. Besides that, the supporting data were obtained from documentation, namely students' learning journals.

\subsection{Trustworthiness}

To confirm the credibility, member-check and triangulation were used in the study. The member-check was employed after the interview transcripts have been arranged. The participants were asked to read the interview transcripts. They were also asked to confirm that the interview transcripts were consistent with the interview result. Besides, the data were triangulated to figure out the same finding from the data which were gained from multiple data collection methods (interview transcripts and students' learning journals). 


\subsection{Data Analysis}

In the study, the data were collected, coded and analyzed by using a constant comparison method (Strauss \& Corbin, 1998). The data analysis started by listening to the recording of the interview carefully to obtain an interpretation and general understanding. Then, the interview was transcribed and coded based on the objective of the study. Finally, the data were analyzed based on the categories. Besides, the data collected from documentation were also analyzed and collected to support the finding obtained from the interviews.

\section{Findings}

The study examined two males EFL student-teachers' metacognitive awareness in Extensive Listening activity. The study revealed what they know about themselves, listening tasks, and listening strategies in the process of learning English through Extensive Listening. Besides that, the study also reported how they conceive it. The data have been categorized based on five aspects of metacognitive awareness namely planning and evaluation, problem-solving, directed attention, mental translation, and personal knowledge.

\subsection{Problem Solving}

The finding showed that Farhan and Andre have a similar strategy in obtaining meaning during Extensive listening activity. When they tried to comprehend English oral text from an English film, they tend to focus on general understanding meaning rather than trying to understand the individual word. Both of them agree that it doesn't matter if they did not understand every single word spoken by a native speaker as long as they can guess and infer the general meaning. Farhan and Andre reported their situation in the following comments:

"I keep enjoying and continue watching my favorite English movies without translating every single word because I know that I will understand full of the story after I watch several scenes." (Farhan) "It's hard to understand the meaning of English Rap Song lyrics, but I believe that I will understand it if I commit to listening to it regularly and repeatedly". (Andre)

The study also reported that Farhan has other strategies to tackle listening difficulties such as using his background knowledge by comparing what he already understood about the topic, using his own experience and knowledge to assist him during the listening process, and adjusting his interpretation every time he realizes that there is a misconception.

To dealt with that situation, Farhan reported;

"Before I listened, I have already known about what is going to be watched. For example, when I wanted to watch the topic about 'traffic' news, I assumed that there will be some keywords regarding the topic such as traffic jam, weather condition, etc. that will help me to prepare and comprehend what I am going to listen." (Farhan) 


\subsection{Mental Translation}

In the study, Farhan avoided translating word by word the whole text in his mind while he was watching an English movie. He only focused on important keywords to comprehend the plot of the story. $\mathrm{He}$ thought that he will understand the general meaning of the movie by only knowing some keywords. Meanwhile, Andre did not use mental translation. He continued to listen without translating in his head. He sometimes used the English subtitle assistance to comprehend the English movie he watched. Nevertheless, He argued that he did not want to always depend on subtitles.

One of the participants reported:

"Not all English movies were provided with English or Indonesian subtitle, so I'm getting used to watching an English movie without subtitles and try to infer meaning from understanding the general idea of the movie." (Andre)

From the statement above, it can be inferred that English student-teachers scarcely use mental translation. The participants tend to elicit meaning from what they can understand from the general idea by using their predictions.

\subsection{Person Knowledge}

From two participants, it was found that they face some difficulties during Extensive Listening. Farhan and Andre assumed that L2 Listening is quite challenging. Farhan argued that he was often confused by similar sounds with different meanings. He was also difficult to catch the meaning because he thought that the speakers spoke too fast. He also argued that he did not familiar with some words spoken by a native English speaker in the movie. Andre also thought that he has difficulties in understanding the meaning.

One of the participants described the situation below:

"Listening to English is so challenging. I got difficulty in differentiating the words which have a similar sound but different in meaning. I sometimes think that there is a problem in my ears because I cannot listen to it clearly. I also feel that native speakers speak to fast before I understand what they say when I was watching an English Movie." (Farhan)

However, although there are a lot of problems in listening to English, they enjoy doing the activity. Farhan keeps doing Extensive regularly since he was in junior High School. He likes He usually search for a silent place and use earphones while listening to avoid distractions from his environment. He argued that he will be more focus and he was able to listen clearly to what native speaker said in the English movie.

Andre is also a person who likes practicing Extensive Listening regularly. He spent more than 3 hours a day only to watch his favorite English Movie. He made Extensive listening as his habit. He also 
likes to do this activity in a comfortable place which is free from noise which distracts his concentration. He also likes to do it in the afternoon or in the evening. He assumed that it is the right time to practice Extensive Listening.

\section{Discussion}

The study scrutinized what kind of Metacognitive Awareness categories used by EFL student-teachers and how they regulated and monitored their mental process in the process of extensive listening outside the classroom. Findings revealed that the participants took advantage of metacognitive awareness. They also recognized various difficulties that appeared during the listening process and know how to tackle the problems. The finding was in line with the study by Goh and $\mathrm{Hu}$ (2013) who found that students were aware of their listening processes and various challenges they faced in the listening activity.

In the study, two participants frequently used problem-solving in Extensive listening rather than other strategies. They argued that they have difficulty to infer meaning when they watched English Movie. However, they tried to use their background knowledge to guess the overall meaning. They are also aware to use strategy to guess the meaning of the oral text they have listened to. It was in line with other studies that revealed that problem-solving strategies have been extensively used by participants rather than other strategies (Altuwairesh, 2016; Esmaeili, 2017). Berne (2004) also found that students used the problem-solving strategy by guessing the meaning based on what they have listened in their past experiences. Goh and $\mathrm{Hu}$ (2013) reported that the students use problem-solving strategies by making inferences about the meaning of words, contexts, and background knowledge. They are also able to monitor and evaluate comprehension during listening with the help of previous knowledge.

The result revealed that one of the participants rarely used mental translation in the listening process and another participant did not use mental translation. One of the participants still used mental translation by translating keywords in his head as he listened to English movies. They avoid translating word by word when they enjoy listening to English Movies. It was in line with other studies that discovered that mental translation was the least used by students (Mohammad et al, 2016; Wulanjani and Indriani, 2019). As Vandergrift (2003) assumed, the less-skilled students more frequently using translation and the more strategic learners used translation less.

Findings also showed that participants used person knowledge to face listening difficulties. Both participants understood that they dealt with different English pronunciation and unfamiliar words which often confused them during the listening activity. It was in line with Li (2013) who found that students had difficulties dealing with unfamiliar vocabularies when they practiced listening activity in which those difficulties demotivated students to do listening. However, the participants of the study were still confidence to perform extensive listening although they coped with various difficulties. It was possibly due to they performed extensive listening in which the goal was to have pleasure. 


\section{Conclusion}

The study discovered the metacognitive listening awareness of two male EFL student-teachers in Extensive Listening. Findings revealed that problem-solving strategies mostly used by EFL students, followed by person knowledge and mental translation. Based on findings, the English teachers should encourage their students not to use word-by-word translation and suggest students to use general understanding to facilitate their listening comprehension. Besides, students can also use their background knowledge to get a better understanding of the listening process. However, the participants of the study have the same gender. Further researchers can conduct a study in which the participants have different gender to figure out whether gender has a significant influence on the use of metacognitive awareness or not. It is also possible to research participants with different age, achievement, or level of education.

\section{References}

[1] Altuwairesh, N. (2016). EFL Saudi Undergraduate Students' Use of Metacognitive Listening Strategies. Arab World English Journal, 7(1), 78-93. https://doi.org/10.24093/awej/vol7no1.6

[2] Anderson, A. and Lynch, T. 1988. Language Teaching: A Scheme for Teacher Education. New York: Oxford University Press

[3] BACON, S. M. (1992). The Relationship between Gender, Comprehension, Processing Strategies, and Cognitive and Affective Response in Foreign Language Listening. The Modern Language Journal, 76(2), 160-178. https://doi.org/10.1111/j.1540-4781.1992.tb01096.x

[4] Berne, J. E. (2004). Listening Comprehension Strategies: A Review of the Literature. Foreign Language Annals, 37(4), 521-531. https://doi.org/10.1111/j.1944-9720.2004.tb02419.x

[5] Bidabadi, F., \& Yamat, H. (2011). The Relationship between Listening Strategies Used by Iranian EFL Freshman University Students and Their Listening Proficiency Levels. English Language Teaching, 4(1), 26. https://doi.org/10.5539/elt.v4n1p26

[6] Brown, S. 2011. Listening myths: Applying second language research to classroom teaching. Ann Arbor: University of Michigan Press.

[7] Byrnes, J. P. (2008). Cognitive Development and Learning in Instructional Contexts. Cognitive Development and Learning in Instructional Contexts.

[8] Costa, A. L. (1985). Developing Minds: A Resource Book for Teaching Thinking. Adolescence (Vol. 37, p. 217).

[9] Day, R. \& Bamford, J. (2002). Top ten principles for teaching extensive reading. Reading in a Foreign Language, 14(2), 136-141.

[10]Dunkel, P. (1991). Listening in the Native and Second/Foreign Language: Toward an Integration of Research and Practice. TESOL Quarterly, 25(3), 431. https://doi.org/10.2307/3586979 
[11]Flavell, J. H. (1979). Metacognition and cognitive monitoring: A new area of cognitive-developmental inquiry. American Psychologist, 34(10), 906-911. https://doi.org/10.1037/0003-066X.34.10.906

[12] Ganschow, L., \& Sparks, R. (2001). Learning difficulties and foreign language learning: A review of research and instruction. Language Teaching. https://doi.org/10.1017/S0261444800015895

[13]Goh, C. C. M. (1998). How ESL learners with different listening abilities use comprehension strategies and tactics. Language Teaching Research, 2(2), 124-147. https://doi.org/10.1177/136216889800200203

[14] Goh, C. C. M. (1999). Teaching Listening in the Language Classroom. Singapore: SEAMEO Regional Language Centre.

[15] Goh, C. C. M. (2000). A cognitive perspective on language learners' listening comprehension problems. System, 28(1), 55-75. https://doi.org/10.1016/S0346-251X(99)00060-3

[16]Goh, C. C. M. (2010). Listening as process: Learning activities for self-appraisal and self-regulation. English Language Teaching Materials: Theory and Practice, 179. Retrieved from http://books.google.com.eres.library.manoa.hawaii.edu/books?hl=en\&lr=\&id=NGTmer7AUSsC\&oi=fnd\&pg=PA179\&ots=8GE9zRxq6\&sig=iP8t8zdUKAwoqrgfbd9d_Me1GxI

[17]Graham, S. (2011). Self-efficacy and academic listening. Journal of English for Academic Purposes, 10(2), 113-117. https://doi.org/10.1016/j.jeap.2011.04.001

[18]Huang, J. (2004). Voices from Chinese Students: Professors' Use of English Affects Academic Listening. College Student Journal, 38(2), 212-223. Retrieved from Doucement View

[19] Mareschal, C. (2002). A cognitive perspective on the listening comprehension strategies of second language learners in the intermediate grades. Unpublished MA thesis, University of Ottawa

[20]Mendelsohn, D. (2001). Listening comprehension: We've come a long way, but . . Contact, 27, 3340.

[21] Miller, L. (2009). Engineering lectures in a second language: what factors facilitate students' listening comprehension? Asian EFL Journal, 11(2), 8-30.

[22]Patton, M. Q. (2002). Qualitative research and evaluation methods. Qualitative Inquiry (Vol. 3rd, p. 598). https://doi.org/10.2307/330063

[23]Renandya, W. A., \& Farrell, T. S. C. (2011). “Teacher, the tape is too fast!" Extensive listening in ELT. ELT Journal, 65(1), 52-59. https://doi.org/10.1093/elt/ccq015

[24]Richards, J. C. (2005). Second Thoughts on Teaching Listening. RELC Journal, 36(1), 85-92. https://doi.org/10.1177/0033688205053484

[25] Rost, M. (1990). Listening in language learning. London: Longman.

[26]Rost, M. (1994). Introducing listening. London: Penguin Books.

[27] Rost, M. (2002). Teaching and researching listening. London: Pearson Education. 
[28]Rost, M. (2002). Teaching and Researching Listening. London, UK: Longman

[29] Rost, M. (2005). L2 listening. In Handbook of Research in Second Language Teaching and Learning (pp. 503-527). Mahwah, New Jersey: Lawrence Erlbaum.

[30]Sternberg, R. J. (1998). Styles of Thinking and Learning. Canadian Journal of School Psychology, 13(2), 15-40. http://dx.doi.org/10.1177/082957359801300204

[31]Strauss, \& Corbin, J. (1998). Basics of Qualitative Research: Second Edition: Techniques and Procedures for Developing Grounded Theory. Basics of Qualitative Research Techniques and Procedures for Developing Grounded Theory (Vol. 2nd, p. 336). Sage Publications.

[32]Thorn, S. (2009). Mining listening texts. Modern English Teacher, 18(2), 5-13

[33] Vandergrift, L. \& Goh, C. C. M. (2012). Teaching and learning second language listening: Metacognition in action. New York: Routledge

[34]Vandergrift, L. (2003). Orchestrating Strategy Use: Toward a Model of the Skilled Second Language Listener. Language Learning, 53(3), 463-496. https://doi.org/10.1111/1467-9922.00232

[35] Vandergrift, L. (2007). Recent developments in second and foreign language listening comprehension research. Language Teaching, 40(3), 191-210. https://doi.org/10.1017/S0261444807004338

[36]Vandergrift, L., \& Tafaghodtari, M. H. (2010). Teaching L2 Learners How to Listen Does Make a Difference: An Empirical Study. Language Learning, 60(2), 470-497. https://doi.org/10.1111/j.14679922.2009.00559.x

[37]Vandergrift, L., Goh, C. C. M., Mareschal, C. J., \& Tafaghodtari, M. H. (2006). The metacognitive awareness listening questionnaire: Development and validation. Language Learning, 56(3), 431-462. https://doi.org/10.1111/j.1467-9922.2006.00373.x

[38]Wenden, A. (1991). Learner Strategies for Learner Autonomy. Prentice Hall, New York.

[39]Wenden, A. L. (1998). Metacognitive knowledge and language learning. Applied Linguistics, 19(4), 515-537. https://doi.org/10.1093/applin/19.4.515 